\section{Fluoride Release/Uptake from Different Orthodontic Adhesives: A 30-Month Longitudinal Study}

Rogério Lacerda dos Santos ${ }^{1}$, Matheus Melo Pithon², Aline Birra Nolasco Fernandes ${ }^{3}$, Fabiola Galbiatti Carvalho ${ }^{1}$, Alessandro Leite Cavalcanti ${ }^{4}$, Delmo Santiago Vaitsman ${ }^{5}$
'Department of Orthodontics and Pediatric Dentistry, UFCG Federal University of Campina Grande, Patos, PB, Brazil

${ }^{2}$ Department of Orthodontics, UESB

- State University of Southwest

Bahia, Jequié, BA, Brazil

${ }^{3}$ Department of Orthodontics, UFRJ - Federal University of Rio de

Janeiro, Rio de Janeiro, RJ, Brazil

${ }^{4}$ Department of Community and Preventive Dentistry, UEPB

- State University of Paraíba, Campina Grande, PB, Brazil

${ }^{5}$ Department of Chemistry, UFRJ

- Federal University of Rio de

Janeiro, Rio de Janeiro RJ, Brazil

Correspondence: Prof. Rogério Lacerda dos Santos, Avenida dos Universitários, $\mathrm{s} / \mathrm{n}$, Rodovia Patos/ Teixeira, Km 1, Santa Cecília, 58700970 Patos, PB, Brasil. Tel: +55-839977-7100. e-mail: lacerdaorto@ hotmail.com lacerdaorto@bol.com.br

Key Words: sodium fluoride, dental materials, adhesives, dental cements.

\section{Introduction}

Dental plaque retained adjacent to orthodontic brackets and bands commonly causes enamel demineralization close to the bracket-tooth junction (1). Thus, orthodontic attachments should be maintained with materials able of releasing fluoride and providing an adequate bond to both enamel and stainless steel wire (2).

It is important to prevent this demineralization, as it has been demonstrated in vivo that these lesions around brackets may be present after only 1 month and may occur in up to $50 \%$ of patients (3). In this context, prevention of this occurrence is of great importance to both orthodontists and patients because the lesions are unaesthetic and potentially irreversible.

Increased attention has been focused on the development of fluoride-releasing orthodontic adhesives $(4,5)$. At present, resin modified glass ionomer cements (RMGICs) and composites have been used in orthodontics with increasing frequency. As conventional GICs have been proven unreliable for bracket bonding (6), some hybrid materials consisting of resin and GIC components have been developed to overcome the problems of moisture sensitivity and low initial mechanical strength, which are characteristics of GICs.

Fluoride-releasing materials can take up fluoride ions from the oral environment as a means of replacing lost fluoride (7). Thus, the recharge of fluoride may contribute to the ability of these materials to provide a long-term inhibitory effect on the enamel demineralization process, because the recharged fluoride is released again and presumably contributes to continuous prevention of these lesions (8).

Nevertheless, studies on fluoride uptake and re-release by orthodontic adhesives in the long term has received little attention (4). Therefore, the purpose of this study was to evaluate the behavior of orthodontic adhesives regarding pre- and post-recharge fluoride release during 30 months, raising the null hypothesis that there is no difference in fluoride release between RMGICs and composites in the long term.

\section{Material and Method Sample Preparation}

Five light polymerized orthodontic adhesives were used: a nonfluoride-releasing composite - Group TXT (Transbond $\mathrm{XT} ; 3 \mathrm{M}$, Monrovia, CA, USA), a fluoride-releasing composite - Group QC (Quick-Cure; Reliance Orthodontics, Itasca, IL, USA), and three RMGICs - Groups FOLC, FOB and MC (Fuji Ortho LC and Fuji Ortho Band; GC Corporation, Tokyo, Japan; and Multi-Cure, 3M).

Initially, samples were made using silicon casts measuring $4 \mathrm{~mm}$ in diameter and $4 \mathrm{~mm}$ high. Each 
orthodontic material was inserted into a silicone cast by a syringe (Centrix; DFL, Rio de Janeiro, RJ, Brazil) in order to avoid air bubble formation.

Sample surfaces were covered with glass slides and a vertical load of $200 \mathrm{gf}$ was applied to standardize the material surfaces. The adhesives were left untouched for $10 \mathrm{~min}$. All materials were handled by a single operator according to the manufacturers' instructions and light polymerized for $40 \mathrm{~s}$ (Radii, SDI, Baywater, Victoria, Australia) (20 s from the top and $20 \mathrm{~s}$ from the bottom).

Fifty samples were prepared, 10 for each cement and 10 for the composite resin. The samples were kept in a humidifier at $37^{\circ} \mathrm{C}$ and $100 \%$ humidity for $30 \mathrm{~min}$. After this period, 2 samples from each group were put into an identified glass container with $8 \mathrm{~mL}$ deionized water (Millipore, Bedford, MA, USA). This procedure was done to facilitate the fluoride detection of the different materials. The glass containers were put into an incubator and kept at $37^{\circ} \mathrm{C}$ throughout the study. The samples were slightly dried every $24 \mathrm{~h}$ by using sheets of absorbent paper and the water in each container was replaced as well. This procedure was performed to prevent fluoride accumulation and to assess the daily fluoride release $(9,10)$.

\section{Fluoride Determination}

The $8 \mathrm{~mL}$ of solution and $2 \mathrm{~mL}$ of deionized water used to wash the samples were mixed and then diluted 5 times, obtaining a total sample of $50 \mathrm{~mL}$. The total ionic force was adjusted with TISAB II in a 1:1 ratio with sample volume. Fluoride concentrations were analyzed with a selective electrode (Thermo Orion model 9609BN; Orion Research Inc., Boston, MA, USA) connected to a ionic analyzer (pH/ ion 450M; Analyzer, São Paulo, SP, Brazil). The electrode was gauged every day by using standard solutions of fluoride $(0.40,0.80,1.60,3.20$, and $6.40 \mathrm{ppm})$. The concentrations of fluoride released from each material were recorded and then converted into $\mu \mathrm{g} / \mathrm{cm}^{2}$ in order to demonstrate the amount of fluoride released per sample area unit.

\section{Experimental Release of Fluoride}

Initially, the fluoride release was measured at time intervals of $1 \mathrm{~h}, 1,7,14,21$ and 29 days. In the first four weeks fluoride release was measured, but there were no recharges with sodium fluoride solution in order to verify the release of intrinsic fluoride of material in this period.

After 4 weeks, the samples were washed with deionized water for $20 \mathrm{~s}$ and their surfaces were slightly dried with disposable paper. Next, the samples were exposed to $0.221 \%$ sodium fluoride ( $\mathrm{NaF}$ ) solution (1000 ppm of fluoride) (11) on day 29 for $2 \mathrm{~min}$ and then washed with deionized water for $20 \mathrm{~s}$. Then the samples were placed in the glass container with $8 \mathrm{~mL}$ of deionized water, and the fluoride release was measured after $24 \mathrm{~h}$ in order to verify the release time of absorbed fluoride. Further evaluations were performed in the days $180,365,540,730$ and 900 and, $24 \mathrm{~h}$ before each evaluation, the samples were exposed to $0.221 \%$ sodium fluoride solution to evaluate the long term ability to rerelease fluoride. Deionized water was used instead distilled water because the former is ion-free, and the presence of ions might mask the results (12).

By measuring fluoride in parts per million in a known volume of water, it was possible to calculate the total amount of fluoride ions released from the specimens. After each reading, the total fluoride released in micrograms was calculated by multiplying the parts per million $(1 \mathrm{ppm}=$ $1 \mu \mathrm{g} / \mathrm{mL}$ ) by the water sample volume $(10 \mathrm{~mL})$. The total fluoride was then divided by the area of the sample disk to obtain the fluoride release in micrograms per square centimeter.

\section{Statistical Analysis}

Fluoride releasing and re-releasing experiments were

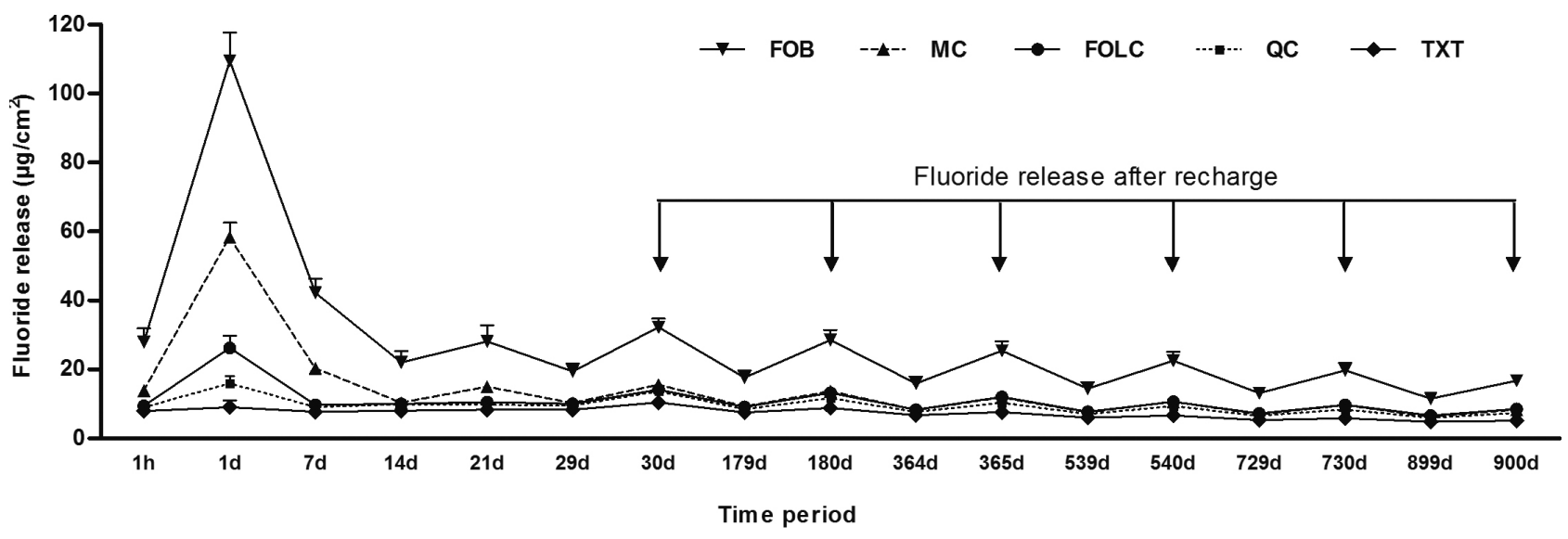

Figure 1. Amount of fluoride released from the materials during the experiment. 
performed using five independent groups ( $\mathrm{n}=10$ specimens by group). The cumulative initial fluoride ion release for 1 month, the re-release of fluoride ions, and fluoride releasing during the subsequent months of observation were analyzed using the Kruskal-Wallis test. Multiple pairwise comparisons were performed using Mann-Whitney test with the Bonferroni correction to compare differences among the materials over time. Significance level was set at 0.05 .

\section{Results}

The fluoride release pattern was similar among the different adhesives, demonstrating greater fluoride ion release in the first day followed by a rapid drop up to the $14^{\text {th }}$ day (Fig. 1). Fluoride release by the orthodontic adhesives before and after recharge in a decreasing order was: RMGICs, fluoride-containing composite and fluoride-free composite. This individual profile of fluoride released by the adhesive groups persisted throughout the entire experiment. Among the RMGICs, FOB presented significantly higher fluoride ion release than FOLC and MC in the first 30 days $(p<0.05)$ (Tables 1 and 2).

From day 14 to day 29 , there were small variations in the amounts of fluoride released by the adhesives. There was an increase in fluoride ion release by all the adhesives on the first day after recharge, and more significantly in the adhesives containing fluoride. The amounts of fluoride ion re-release decreased starting from the second fluoride recharging.

Fluoride release in the time intervals of $30,180,365,540$, 730 and 900 days was relatively consistent in spite of the overall fluoride ion re-release being lower. There was also a gradual reduction in fluoride ion uptake and re-release capacity. The amount of fluoride released by FOB was larger in comparison with the other adhesive, with statistically significant differences ( $p=0.001)$ (Tables 1 and 2).

In the long term, Groups FOLC and MC demonstrated a similar performance, without statistically significant difference ( $p>0.05$ ). The composites released a low quantity of fluoride. However, the fluoride ion uptake and re-release capacity of Group QC was statistically significant $(p<0.05)$ during the experiment. Although there was no description of fluoride in the composition of Group TXT, surprisingly, this material demonstrated a very small, but detectable amount of fluoride release during the study.

In the 30th month after fluoride recharge, Groups TXT and QC no longer presented statistically significant difference $(p=0.076)$.

\section{Discussion}

Effective prevention against enamel demineralization adjacent to orthodontic attachments is necessary, since Orthodontic brackets and bands act as biofilm retaining structures capable of causing demineralization during orthodontic treatment $(1,13)$.

Among the materials evaluated in this study, the

Table 1. Fluoride release before and after recharge with sodium fluoride from baseline to 180 days (in $\mu \mathrm{g} / \mathrm{cm}^{2}$ )

\begin{tabular}{lccccccccc}
\hline Group & $1 \mathrm{~h}$ & $1 \mathrm{~d}$ & $7 \mathrm{~d}$ & $14 \mathrm{~d}$ & $21 \mathrm{~d}$ & $29 \mathrm{~d}$ & $30 \mathrm{~d}$ & $179 \mathrm{~d}$ & $180 \mathrm{~d}$ \\
\hline TXT & $5.96(1.52) \mathrm{a}$ & $7.07(1.97) \mathrm{a}$ & $5.73(1.37) \mathrm{a}$ & $6.07(0.88) \mathrm{a}$ & $6.35(1.23) \mathrm{a}$ & $6.32(0.92) \mathrm{a}$ & $8.41(0.91) \mathrm{a}$ & $5.51(0.75) \mathrm{a}$ & $6.82(0.81) \mathrm{a}$ \\
QC & $6.98(0.81) \mathrm{a}$ & $13.91(2.14) \mathrm{b}$ & $7.02(0.79) \mathrm{a}$ & $7.30(0.61) \mathrm{a}$ & $7.79(0.89) \mathrm{a}$ & $7.39(0.84) \mathrm{a}$ & $11.70(0.77) \mathrm{b}$ & $6.49(0.90) \mathrm{a}$ & $9.70(0.93) \mathrm{b}$ \\
FOLC & $9.47(0.85) \mathrm{b}$ & $26.27(3.49) \mathrm{c}$ & $9.71(0.73) \mathrm{b}$ & $10.03(0.41) \mathrm{b}$ & $10.50(0.62) \mathrm{b}$ & $10.09(0.69) \mathrm{b}$ & $14.13(1.02) \mathrm{c}$ & $9.12(0.55) \mathrm{b}$ & $13.22(0.72) \mathrm{c}$ \\
FOB & $27.94(4.04) \mathrm{c}$ & $109.55(8.24) \mathrm{d}$ & $42.27(4.02) \mathrm{c}$ & $22.05(3.31) \mathrm{c}$ & $28.18(4.54) \mathrm{c}$ & $19.48(2.21) \mathrm{c}$ & $32.29(2.41) \mathrm{d}$ & $17.62(2.10) \mathrm{c}$ & $28.51(2.94) \mathrm{d}$ \\
MC & $13.83(1.52) \mathrm{d}$ & $58.34(4.16) \mathrm{e}$ & $20.38(1.37) \mathrm{d}$ & $10.38(0.88) \mathrm{b}$ & $14.99(1.23) \mathrm{d}$ & $10.28(0.95) \mathrm{b}$ & $15.50(0.80) \mathrm{c}$ & $9.22(0.84) \mathrm{b}$ & $13.6(1.12) \mathrm{c}$ \\
\hline
\end{tabular}

$\mathrm{N}=10$, Mean (standard deviation). Different letters indicate statistically significant difference among the groups for the same period of time ( $<<0.05)$.

Table 2. Fluoride release before and after recharge with sodium fluoride from 364 to 900 days (in $\mu \mathrm{g} / \mathrm{cm}^{2}$ )

\begin{tabular}{lcccccccc}
\hline Group & $364 \mathrm{~d}$ & $365 \mathrm{~d}$ & $539 \mathrm{~d}$ & $540 \mathrm{~d}$ & $729 \mathrm{~d}$ & $730 \mathrm{~d}$ & $899 \mathrm{~d}$ & $900 \mathrm{~d}$ \\
\hline TXT & $4.73(0.66) \mathrm{a}$ & $5.6(0.73) \mathrm{a}$ & $4.0(0.81) \mathrm{a}$ & $4.6(0.67) \mathrm{a}$ & $3.3(0.70) \mathrm{a}$ & $3.89(0.62) \mathrm{a}$ & $2.8(0.55) \mathrm{a}$ & $3.18(0.44) \mathrm{a}$ \\
QC & $5.69(0.70) \mathrm{a}$ & $8.3(0.87) \mathrm{b}$ & $5.1(0.79) \mathrm{a}$ & $7.3(0.88) \mathrm{b}$ & $4.25(0.72) \mathrm{a}$ & $6.57(0.72) \mathrm{b}$ & $3.98(0.69) \mathrm{a}$ & $5.32(0.77) \mathrm{a}$ \\
FOLC & $8.39(0.74) \mathrm{b}$ & $12.0(0.96) \mathrm{c}$ & $7.93(0.77) \mathrm{b}$ & $10.68(0.90) \mathrm{c}$ & $7.31(0.85) \mathrm{b}$ & $9.75(0.77) \mathrm{c}$ & $6.62(0.79) \mathrm{b}$ & $8.56(0.63) \mathrm{b}$ \\
FOB & $15.94(1.99) \mathrm{c}$ & $25.44(2.70) \mathrm{d}$ & $14.43(1.95) \mathrm{c}$ & $22.5(2.66) \mathrm{d}$ & $13.2(1.10) \mathrm{c}$ & $19.73(2.23) \mathrm{d}$ & $11.57(1.20) \mathrm{c}$ & $16.7(1.61) \mathrm{c}$ \\
MC & $8.25(0.80) \mathrm{b}$ & $11.83(0.90) \mathrm{c}$ & $7.78(0.64) \mathrm{b}$ & $10.65(0.93) \mathrm{c}$ & $6.98(0.55) \mathrm{b}$ & $9.7(0.68) \mathrm{c}$ & $6.29(0.60) \mathrm{b}$ & $8.3(0.86) \mathrm{b}$ \\
\hline
\end{tabular}

$\mathrm{N}=10$, Mean (standard deviation). Different letters indicate statistically significant difference among the groups for the same period of time $(p<0.05)$. 
nonfluoride-containing composite showed the lowest fluoride ion release, detectable throughout the experiment. However, all fluoride-releasing materials showed that fluoride-release began with a higher amount of fluoride being released from RMGICs $24 \mathrm{~h}$ after the initial setting, and decreased on days 3,7 , and 14 . From day 14 to day 29, fluoride release stabilized, as reported elsewhere (9-12). This characteristic is clinically relevant to the materials used for attaching orthodontic bands (14) and bonding brackets (13). The initial burst of fluoride ion release during the first few days forms calcium fluoride on the enamel surface as soon as the adhesives are exposed to the oral cavity environment (15). This may play a significant protective role in remineralizing (13) etched enamel (16), in addition to the bactericidal effect provided and/or bacteriostatic properties present after bracket placement (8). RMGICs maintained fluoride release with a gradual drop after the 1st month, with Fuji Ortho Band demonstrating higher fluoride release in comparison with Fuji Ortho LC and Multi-Cure.

The highest fluoride ion release from RMGICs was attributed to the acid-base setting reaction by the sum of the powder and liquid, or by fluoroaluminosilicate in paste form, which results in fluoride ion release $(12,17)$. The higher initial release is partly due to surface wash of the set material to the majority of glass species reacting with the polyacid. The following phase of relative stabilization after the initial phase has been explained by diffusion of fluoride ions through pores (18) and cracks and the diffusion through the bulk of the adhesives representing a continuing reaction in the long-term (19).

Fluoride ion release from composites was significantly lower than from RMGICs, because fluoride ion release was mainly the result of the diffusion of water-soluble fluoride ions from the composite into the local environment $(6,12,20)$. Although relatively consistent, due to the lower overall fluoride ion re-release and release from the beginning until the 30th month, this release may also have a significant effect on the demineralization/remineralization process, because the fluoride release was sustained (21). This adds up to the fact that release and re-release of fluoride ions after re-fluoridation may be relatively equivalent to the effect of the use of dentifrices and/or mouth washes (13) in the long term. Interestingly, Transbond XT showed fluoride ion release before and after fluoride application. This might be due to fluoride diffusion into pores and/or cracks within the adhesive and/or surface-retention of fluoride after exposure to fluoride, followed by subsequent release $(18,22)$. As composites are the most commonly used direct bonding agents, the ability to take up and release low levels of fluoride ions indicates the possible benefit of methods of fluoride application in these materials $(12,17)$. In spite of the better performance of Quick-Cure composite compared with the nonfluoride-containing composite, both showed low capability of acting as an effective fluoride reservoir in comparison with the RMGICs. This may be due to relative impermeability of composites compared with RMGICs, which have greater porosity $(1,12,18,23)$.

A previous study reported that the theoretical level of fluoride to inhibit enamel demineralization in the immediate proximity of orthodontic adhesives is in the range of $1.3 \mathrm{mg} \mathrm{F} / \mathrm{cm}^{2} /$ day (17), which is a lower value than those obtained with the materials tested in the present study. Nevertheless, both the magnitude and the duration of the anticariogenic effects of fluoride depend mainly on its concentration and retention time within the oral cavity (24). Following this rationale, the use of materials with a higher fluoride ion re-release capacity and prolonged fluoride release should be considered in conjunction with regular fluoride application. This would be particularly beneficial to patients at high caries risk in view of the long duration of the orthodontic treatment $(14,25)$.

Within the limits of this study, the null hypothesis was rejected. Although some materials present similar performance, the RMGIC Fuji Ortho Band and the composite Quick-Cure presented higher fluoride release and re-release capacity when recharged.

\section{Resumo}

0 objetivo deste estudo foi testar a hipótese nula de que não há nenhuma diferença de liberação de flúor entre cimentos de ionômero de vidro reforçados com resina (CIVRRs) e entre compósitos em longo prazo. Os materiais foram divididos em 5 grupos: um compósito não liberador de flúor - Grupo TXT (Transbond XT), um compósito liberador de flúor - Grupo QC (Quick-Cure), e três CIVRRs - Grupos FOLC, FOB e MC (Fuji Ortho LC, Fuji Ortho Band e Multi-Cure). A liberação de flúor foi medida em intervalos de tempo de $1 \mathrm{~h}, 1,7,14,21$ e 29 dias, seguido por outras avaliações realizadas aos 6, 12, 18, 24 e 30 meses, utilizando um eletrodo ion seletivo conectado a um analisador de íons. Liberação de flúor e experimentos de re-liberação foram avaliados usando o teste de Kruskal-Wallis e teste Mann-Whitney com correção de Bonferroni. A quantidade de flúor liberado pelo FOB foi maior em comparação com os outros adesivos $(p=0,001)$. Em longo prazo, FOLC e MC demonstraram um desempenho semelhante $(p>0,05)$. Os compósitos liberaram uma baixa quantidade de fluoreto, no entanto, a capacidade de captação do íon fluoreto e re-liberação do $\mathrm{OC}$ foi estatisticamente significante $(p<0,05)$ durante o experimento. Em conclusão, a hipótese nula foi rejeitada, o CIVRR Fuji Ortho Band e o compósito Quick-Cure apresentaram maior liberação e capacidade de re-liberação de flúor quando recarregados.

\section{Acknowledgements}

The authors would like to acknowledge the National Council for Scientific and Technological Development (CNPO) for research funding.

\section{References}

1. Pascotto RC, Navarro MF, Capelozza Filho L, Cury JA. In vivo effect of a resin-modified glass ionomer cement on enamel demineralization around orthodontic brackets. Am J Orthod Dentofacial Orthop 2004;125:36-41.

2. Cohen WJ, Wiltshire WA, Dawes $\mathrm{C}$, Lavelle CL. Long-term in vitro 
fluoride release and rerelease from orthodontic bonding materials containing fluoride. Am J Orthod Dentofacial Orthop 2003;124:571576.

3. Artun J, Brobakken BO. Prevalence of carious white spots after orthodontic treatment with multibonded appliances. Eur J Orthod 1986;8:229-234.

4. Chin MY, Sandham A, Rumachik EN, Ruben JL, Huysmans MC. Fluoride release and cariostatic potential of orthodontic adhesives with and without daily fluoride rinsing. Am J Orthod Dentofacial Orthop 2009;136:547-553.

5. Gjorgievska E, Nicholson WJ, Iljovska S, Slipper I. The potential of fluoride-releasing dental restoratives to inhibit enamel demineralization: an SEM study. Prilozi 2009;30:191-204.

6. Wiegand A, Buchalla W, Attin T. Review on fluoride-releasing restorative materials - fluoride release and uptake characteristics, antibacterial activity and influence on caries formation. Dent Mater 2007;23:343-362.

7. Itota $T$, Carrick TE, Yoshiyama M, McCabe JF. Fluoride release and recharge in giomer, compomer and resin composite. Dent Mater 2004;20:789-795.

8. Ahn SJ, Lee SJ, Lee DY, Lim BS. Effects of different fluoride recharging protocols on fluoride ion release from various orthodontic adhesives. J Dent 2011;39:196-201.

9. Kuvvetli SS, Tuna EB, Cildir SK, Sandalli N, Gencay K. Evaluation of the fluoride release from orthodontic band cements. Am J Dent 2006;19:275-278.

10. Wheeler AW, Foley TF, Mamandras A. Comparison of fluoride release protocols for in-vitro testing of 3 orthodontic adhesives. Am J Orthod Dentofacial Orthop 2002;121:301-309.

11. Okuyama K, Murata Y, Pereira PN, Miguez PA, Komatsu H, Sano H. Fluoride release and uptake by various dental materials after fluoride application. Am J Dent 2006;19:123-127.

12. Cacciafesta V, Sfondrini MF, Tagliani P, Klersy C. In-vitro fluoride release rates from 9 orthodontic bonding adhesives. Am J Orthod Dentofacial Orthop 2007;132:656-662.

13. Huang GJ, Roloff-Chiang B, Mills BE, Shalchi S, Spiekerman C, Korpak AM, et al.. Effectiveness of MI Paste Plus and PreviDent fluoride varnish for treatment of white spot lesions: A randomized controlled trial. Am J Orthod Dentofacial Orthop 2013;143:31-41.
14. Elaheh Vahid-Dastjerdi E, Borzabadi-Farahani A, Pourmofidi-Neistanak $H_{1}$ Amini N. An in-vitro assessment of weekly cumulative fluoride release from three glass ionomer cements used for orthodontic banding. Prog Orthod 2012;13:49-56.

15. Rolla G, Saxegaard E. Critical evaluation of the composition and use of topical fluorides, with emphasis on the role of calcium fluoride in caries inhibition. J Dent Res. 1990;69 Spec No:780-785; discussion 820-783.

16. Wiltshire WA. Determination of fluoride from fluoride-releasing elastomeric ligature ties. Am J Orthod Dentofacial Orthop 1996;110:383-387.

17. McNeill CJ, Wiltshire WA, Dawes C, Lavelle CL. Fluoride release from new light-cured orthodontic bonding agents. Am J Orthod Dentofacial Orthop 2001;120:392-397.

18. Gao W, Smales RJ. Fluoride release/uptake of conventional and resinmodified glass ionomers, and compomers. J Dent 2001;29:301-306.

19. Swartz ML, Phillips RW, Clark HE. Long-term F release from glass ionomer cements. J Dent Res 1984;63:158-160.

20. dos Santos RL, Pithon MM, Vaitsman DS, Araujo MT, de Souza MM, Nojima MG. Long-term fluoride release from resin-reinforced orthodontic cements following recharge with fluoride solution. Braz Dent J 2010;21:98-103.

21. ten Cate JM. Current concepts on the theories of the mechanism of action of fluoride. Acta Odontol Scand 1999;57:325-329.

22. Pithon MM, dos Santos RL, Ruellas ACO, Nojima LI, Sant'anna EF. In vitro evaluation of fluoride release of orthodontic bonding adhesives. Orthodontics 2011;12:290-295

23. Preston AJ, Higham SM, Agalamanyi EA, Mair LH. Fluoride recharge of aesthetic dental materials. J Oral Rehabil 1999;26:936-940.

24. Ogaard B. White spot lesions during orthodontic treatment: mechanisms and fluoride preventative aspects. Semin Orthod 2008;14:183-193.

25. Dijkman GE, de Vries J, Lodding A, Arends J. Long-term fluoride release of visible light-activated composites in vitro: a correlation with in situ demineralisation data. Caries Res 1993;27:117-123.

Received April 29, 2013 Accepted July 6, 2013 